2-3002 Lombard A \& du Preez J

\title{
CHALLENGES FOR BUILDING PARTNERSHIPS IN SOCIAL DEVELOPMENT
}

Prof A Lombard, professor Department of Social Work, University of Pretoria and Janet du Preez, Consultant, Social Development

\begin{abstract}
The primary goal of partnerships in social development is to strategically join efforts to reduce poverty, address inequalities and social injustices through the redistribution of resources, and through social and economic development programmes. This can only be achieved when there is a true commitment from all partners involved to take up the challenges of building partnerships which could provide a negotiated framework for a partnership strategy for social development. These challenges include understanding the changing role of the state, redefining partnerships, empowerment of NGOs to be service deliverers and advocates, the creation of an enabling environment, recognition and balancing of social development partners' strengths and weaknesses, an agreement on the social development agenda and a plan for sustainable social development. Although a partnership strategy for social development needs to be in place to provide broad guidelines, each kind and level of partnership need to be uniquely negotiated, planned, designed and maintained.
\end{abstract}

\section{INTRODUCTION}

The Reconstruction and Development Programme (RDP), designed and developed by the ANC to coincide with the first democratic elections in South Africa in 1994, provided the socio-economic policy framework which was to become the vehicle to change the face of development in South Africa. The RDP shifted the focus from economic development as the sole driver of development to ensuring that social and human development completed the development triangle and it gave rise to the government adopting a developmental approach to service delivery. This approach was further strengthened by the World Summit for Social Development in Copenhagen (1995) where South Africa, in conjunction with the rest of the world, took up the challenge of social development to reduce global poverty by half in 2015 .

The many faces of poverty (Estes, 1999; May, 1998) and the multi-sectoral nature of social development require the inputs of various role players if poverty is to be combated meaningfully and there is to be an impact on poverty reduction. The scale and urgency of the situation demand joint efforts. In some cases the complexity and cross-cutting nature of the issues, such as HIV/AIDS and unemployment, call for integrated approaches that cannot be provided by single institutions acting alone. Hence the real challenge for there to be an impact on the mass poverty that confronts the world lies within building partnerships for social development.

The building of partnerships for social development requires a clear understanding of what the purpose and meaning of 'partnerships' for social development entail, who the role players are, what roles they play within the partnership, and what the challenges are.

\section{PURPOSE OF PARTNERSHIPS FOR SOCIAL DEVELOPMENT}

The primary goal of partnerships in social development is to strategically join efforts to reduce poverty, address inequalities and social injustices through the redistribution of resources, and 
through social and economic development programmes. This requires a commitment to the socially excluded.

Matube (2000:1) is of the opinion that meaningful partnerships are rare to find. At the same time, she argues, "unity is strength and, hence, in partnerships success is guaranteed. All suppliers of resources for sustainable development can enter into partnerships for win-win results".

The purpose of partnerships for social development can only be achieved when there is a true commitment from all partners involved. To obtain this commitment, the partners should have a clear understanding of what the partnership entails. Fowler (2000:47) concurs that a true partnership displays full, mutual support for the identity and the well-being of each role player, and for all aspects of the work.

\section{PARTNERSHIPS FOR SOCIAL DEVELOPMENT DEFINED}

Without a clear understanding of what a partnership entails and who the respective partners are, no meaningful partnership for sustainable social development can be established or maintained (Lombard \& Jansen van Rensburg, 2001:326).

Fowler (2001:27) concurs that the concept of partnership is not always understood by the partners and states, furthermore, that the concept has been stretched in many directions and interpreted in many ways. Consequently the phrase "partnership in development" has become virtually meaningless and discredited, even "more so because too often it camouflages aid-related relationships that are unbalanced, dependency-creating and based on compromise in favour of the powerful" (Fowler, 2000:27).

To attenuate or remove the institutional dysfunctions associated with aid, Fowler (2000:27) proposes that greater equity, co-responsibility and ownership should be brought into the aid process; that relationships other than partnerships should be recognised; and that different relationships require the open negotiation of different rights and obligations of the parties involved and the establishment of "honest brokers".

In view of the fact that, when it comes to partnerships, "one size does not fit all" (Fowler, 2000:27), Lombard and Jansen van Rensburg (2001:326) argue that the building of partnerships is a process that develops on a continuum from a lower level of collaboration to a higher level of intensity. The level of partnership depends on how deeply the sharing of resources goes, ranging from networking, co-operation, co-ordination, collaboration to the forming of coalitions.

The critical partners for social development include the state, the private sector, donor organisations (also funding agencies and the business sector), the non-governmental sector (NGOs), encompassing community-based (CBO), mass-based (MBO) and faith-based organisations (FBO) and the community at large (Swanepoel \& De Beer, 1996:28). Each of these partners may have partnerships within themselves, in other words intra-partnerships and/or interpartnerships with other role players. NGOs, for example, may have intra-partnerships among themselves, with other civic organisations and at the same time have inter-relationships with people who are poor or excluded; with governmental bodies on various levels (national, provincial and local) and with funders, be they official or private (Fowler, 2000:45). The nature of the relationship will determine the level of partnership as outlined by Lombard and Jansen van Rensburg (2001).

A strong NGO intra-partnership is important for an inter-partnership between NGOs and government since, if the NGO sector is not strong and united, it will be weak as a lobby and advocacy entity for civil society (Lombard \& Jansen van Rensburg, 2001:331). Ideally, each 
relationship will be tailored to the goals and circumstances of the parties concerned in equitable and mutually beneficial ways.

It is clear, therefore, that there is no blueprint for partnerships. Fowler (2000:47) agrees that a true partnership is holistic and comprehensive, with no limits, in principle, to what the relationship embraces.

\section{CHALLENGES FOR BUILDING PARTNERSHIPS}

A partnership strategy for social development should include the following challenges:

\section{Understanding the changing role of the state}

The World Development Report (1997) looked specifically at "The State in a Changing World" and focused particularly on the effectiveness (or otherwise) of the state. It defined a new role for the state in order to meet the demands of a globalising economy. The global integration of economies and the spread of democracy have narrowed the scope for arbitrary and capricious behaviour. Governments are no longer seen as direct providers of growth - rather, the state is to be a partner, catalyst and facilitator. Furthermore, this report argues that the financing of infrastructure and services should be separated from delivery and that a "competitive, private provider" should be used. According to Fowler (2001:11), this is an extension of the political changes that took place in the North in the early 1980s. At that time the market was widely seen as replacing governments as the engine of growth and progress. In practice, this has meant the increased privatisation of state service delivery.

In South Africa this approach has been adopted by the government, hence the emergence of Private Public Partnerships (PPPs) and Municipal Community Partnerships (MCPs). In PPPs the "partner" is the private sector, whereas civil society organisations are expected to play a role in MCPs. According to Cranko and Khan (1999:30), these partnerships are defined as having three broad purposes:

- Extending service delivery to improve access;

- Strengthening the democratic social contract; and

- Increasing effectiveness of government.

From this perspective the following underlying assumptions of government become apparent (Cranko \& Khan, 1999:30):

- Government sees the lack of access to basic services as a key development problem;

- Citizens have rights, but these should be exercised within the framework of co-operation, collaboration and negotiation (rather than contention and opposition);

- Government's success is dependent on its relationship with others - it needs civil society organisations.

Within these assumptions there are important messages for civil society and other role players. They begin to inform civil society as to what government does and does not believe about development as well as what it might want from its partners. However, what is critical is government's recognition that it needs partners if it is to do its work. Matube (2000:5) states that NGOs' economic force, commitment, skills and capacity are a known fact and what they lack most is money. She therefore asks: "Is there therefore any reason why the Government cannot contract 
the NGO sector's energies to do what they fail to do? This is what partnerships are all about". Hence, in the same way that the approach was adopted for MCPs, government should outsource services to NGOs, since they have always been in close contact with the poor and have the skills and capacity to deliver at a grassroots level. Furthermore, NGOs also have the ability to be much more effective, efficient and capable than the state in terms of delivering services. However, to live up to these expectations, NGOs will need to be clear on their strategic position and on what basis they will engage as government's partners.

\section{Redefining partnerships}

Fowler (2001:17) describes the features of partnerships as follows:

- Working together to accomplish agreed results and accepting joint responsibility for achieving them;

- Partnership carries with it long-term involvement;

- Partnership requires defined mutual roles and responsibilities - as covenants not contracts;

- Partnership is about trust, respect, integrity, accountability and equality;

- Partnership requires an acceptance of the principle that the local organisation has the right to set the final agenda for its own work;

- Partnership must not lead to a situation where the link between an organisation's constituency and its leadership is weakened;

- When negotiating relations or contributions from outside the 'partnership', the spirit and letter of an existing partnership must be taken into account and respected;

- Within a partnership, neither party can unilaterally accept other relational conditions that materially influence the partnership;

- Partnership must not alter the basic priorities related to the identity, vision and values of any of the organisations;

- An underlying assumption of partnership co-operation is that the organisations concerned will become more competent in reaching their goals beyond this specific relationship.

The challenge for all partnerships within the development arena is to use the above features as a yardstick to measure the partnership. However, the question needs to be asked if the above characteristics are reflected in all partnerships. It would be naïve to answer in the affirmative, as partners work with one another in diverse ways, and each mode of interacting has characteristics that serve different needs and purposes. As already indicated, effective partnerships, like all relationships, go through various phases and take time to develop. Throughout the life span of the partnership, change and growth occur - in the people involved, their organisations, the partnership itself and the target group.

Fowler (2001:17) suggests that there is a need to identify sufficiently distinctive ways of relating that may help to build a negotiating framework and he puts forward a set of relational principles that can assist partners in building this framework:

- Not every relationship in development is a "partnership" and nor should it be. To work well the development system needs all sorts of relationships; partnership is but one of them; 
- A " partnership" is the most far-reaching in terms of the depth and breadth of rights and obligations that can be agreed;

- A healthy relationship of any type is characterised by an agreed level of mutuality and balance in terms of the rights and obligations of the parties concerned.

These principles provide a foundation for constructing a negotiating framework that could lead to a greater balance and relational empowerment of partners. Within this negotiated framework partnerships develop a social accord that takes into account the short- and long-term development goals of communities. Processes designed to develop such partnerships must be inclusive, open and allow for critical debate and reflection on past and present responses if they are to be effective. Government has to ensure that there is a commitment to developing new partnerships in development using the wealth of experience of NGOs and voluntary organisations that have played such critical roles in the past. Within this framework partnerships that bring the voice of the people and broaden participation, especially of the poor and marginalised, into the centre of development are critical for sustainability. The challenge is to tap the community's reservoir of social capital rather than work against it. The benefits are evidenced in smoother implementation, greater sustainability and better feedback on progress and successes. The redefinition of partnership within a negotiated framework emphasises that a partnership approach is better than the top-down approach, which fails most of the time. South Africa's past history attests to this.

It can be concluded that the challenge for redefining a partnership should be embedded in a negotiated framework. It is people who catalyse partnerships for development and who bring people, organisations and other role players together to work toward achieving a common purpose rooted in jointly understood problems and/or opportunities. Within this context partnerships are based on shared values in practice and evolve into interdependent, mature relationships characterised by each partner being equally valued, the ongoing exchange of ideas, power, learning resources, and the equitable distribution of various benefits (Foulis, 2001:13).

\section{Empowerment of NGOs to be service deliverers and advocates}

For the purpose of this paper NGOs include the formal and informal welfare sector, CBOs and FBOs.

As partners in social development NGOs can reduce poverty and social exclusion through the following (Foulis, 2001:13):

- Direct service delivery to vulnerable groups, including women, children, the aged and people with disabilities;

- Improving access to basic services;

- Fostering democracy;

- Influencing public policies;

- Advocacy for the poor;

- Providing information systems;

- Accountability and participation;

- Action research; 
- Being watchdogs of the public good and safeguarding the interests of disadvantaged sections of society;

- Facilitating political tasks that include pushing for policy reforms, exacting civic compliance on government and business behaviour and fostering "good governance".

(White Paper for Social Welfare, 1997:30; Fowler, 2000:iv; 12)

It is important to acknowledge that NGOs and other civil society organisations hold their own assumptions about partnerships. Those organisations with a more technical orientation have often been content to work within the framework of service delivery, such as MCPs. Others who push for social change, such as those in the social development arena, have emphasised the importance of partnership in tackling inequalities in power, resources and decision making. Their orientation to partnership has largely been rights based and has frequently drawn on the language of democracy.

The claim of NGOs to work in the interest of others (the target group/beneficiaries) has sometimes meant that their own interests have been less clear. However, there are a number of factors that have motivated NGOs to enter into partnerships. The need for money is frequently cited as a reason. In some cases this has been about enabling an organisation to continue doing important and relevant work. In other cases it has been about keeping an organisation going and keeping people employed.

That self-interest is a strong feature of the field of partnership does not warrant its dismissal. What is important is that NGOs' voices are not those of the privileged - those of the state and donors are much more visible and prevalent. The challenge for NGOs is that they need to be alert and to look critically at both the notion and practice of partnering in order to develop positions that allow them to be influential. Furthermore, some of the shifts towards more participatory approaches to development - evident in agencies such as the UNDP (United Nations Development Programme) and various departments within the South African government - present opportunities for civil society organisations to look creatively and proactively at the possibilities presented by such commitments to citizen involvement in decision making (Foulis, 2001:13).

To ensure strong partnerships with Government a vibrant civil society is required. If civil society does not take up the challenge to be vibrant, it will decrease its bargaining power with government. NGOs cannot advocate for the rights of people if they are seen to be in cahoots with government. If nobody challenges government any longer, then all partners, including the government, should be concerned whether the development efforts are still targeting the poorest of the poor. Government wants its partners to challenge, if these challenges will improve service delivery.

In the mid-1990s the National Social Services and Welfare Forum formed a strong concerned group that was recognised by government as a voice for the NGO welfare sector. This body lost momentum and has not as yet been fully reactivated as a lobbying body on behalf of NGOs. Such forums can help to regenerate some of the lost vibrancy of civil society and can also raise a collective voice.

\section{Creation of an enabling environment}

Government should facilitate an enabling environment for integrative social and developmental services, and at the same time account for the distribution of finances in terms of the poor, diversity and equality (Lombard and Jansen van Rensburg 2001:340). This enabling environment should be created through policies, legislation and resources (White Paper for Social Welfare, 
1997:44). The adoption of a developmental paradigm for social welfare that is embedded in social development provides an opportunity to create such an enabling environment for the welfare sector in South Africa.

South Africa played a leading role in initiatives such as the African Renaissance, the African Union, the New Partnership of Africa's Development (NEPAD) and the South African Development Community (SADC), which are indicators of African countries' commitment to building a new continent of democracy, peace and economic stability (Lombard, 2002:1). In South Africa macro policies such as the Reconstruction and Development Programme (RDP) and the Growth, Employment and Redistribution (GEAR) strategy are attempts to integrate social and economic development.

All government departments are responsible for reducing poverty and therefore promoting social development. The Poverty Reduction Strategy of the Gauteng Department of Social Services and Population Development states that "the government has identified the National Programme of Action as an instrument by which the commitment to the poor can be carried out. It is a mechanism for identifying all plans for poverty reduction by government departments, nongovernmental organizations, business organizations and places of learning and religious institutions. It will ensure that all plans converge into a single co-coordinated framework provided by the War on Poverty Forum so as to realize the goals set by the World Summit for Social Development, the Reconstruction and Development Programme and the commitment for a better life for all" (Poverty Reduction Strategy, Gauteng Department of Social Services and Population Development, 2003:12).

Through the Poverty Hearings, the Job Summit, and the Poverty and Inequality Report several priority areas were identified for poverty reduction. The policy priorities adopted by the Task Team for the National Programme of Action for the Eradication of Poverty for the next five years include the following:

- Service delivery;

- A consolidated rural development strategy;

- Increased education and public awareness on constitutional rights;

- Advocacy and information dissemination;

- The targeting of the most vulnerable groups, especially the children, older persons and youth, people with disability and women;

- Access to credit for the economically marginalised;

- Job creation to reduce unemployment;

- Quality public services;

- Greater access to public services and goods;

- A wider social services net;

- The reduction of crime and corruption.

(Poverty Reduction Strategy, Gauteng Department of Social Services and Population Development, 2003:12) 
It is important to note that the National Programme of Action for the Eradication of Poverty is not a separate plan for the eradication of poverty, but an integration of all the policies and plans developed by the separate bodies of the War on Poverty Forum to foster for "a better life for all"( Poverty Reduction Strategy, Gauteng Department of Social Services and Population Development, 2003:12-13). The national government has allocated a special budget for special development employment and social development programmes since 1999. Over the last four years the Gauteng Department of Social Services and Population Development has made approximately R50 million available for this purpose (Poverty Reduction Strategy, Gauteng Department of Social Services and Population Development, 2003:17).

The unfortunate aspect is that, while the intention of government is noble, the pace of delivery is extremely slow. Consequently, because the scale of poverty is so great, the state has resorted to food security programmes as a short-term poverty-relief measure, which is basically contrary to the developmental approach. The challenge for the administration that is currently implementing the programme is to make it developmental in nature.

Government prides itself on alleviating poverty through social security and short-term poverty relief to vulnerable groups. Although the social grant system protects vulnerable individuals, families and communities, its long-term sustainability needs to be questioned. Hence, the Report on a Comprehensive Social Security system for South Africa (2002) is intended to address poverty in a comprehensive manner and to proactively ensure that policies and legislation are in place to make a contributory social security scheme compulsory for all employed South Africans. Social grants cannot be a permanent option for unemployed families, neither from an economic burden viewpoint, nor from the perspective of the beneficiaries' self-esteem. In fact, long-term receipt of social grants will only contribute towards the further social exclusion of the poor (Lombard, 2002:2). The principle of grants together with social services must be integrated into all programmes.

Dr Zola Skweyiya, Minister of Social Development, in his budget vote speech (15 May, 2003) to the National Assembly in March, pledged to accelerate the pace of delivery of social development programmes and grants, while empowering millions of poor citizens of South Africa. He stated: "Indeed the vulnerable of our society, in particular children, older persons, people with disabilities, people infected with and affected by HIV/AIDS and other diseases, are more than ever before, beginning to feel that the government is indeed taking bold steps to make them masters of their own destinies. I did once reiterate that children must come first in all that we do" (Budget Vote Speech, 2003). While there is no doubt that social grants alleviate poverty, it is important to give an account of what the bold steps refer to - not only from the government as a service provider, but also in relation to the government's perspective of partnerships with NGOs to deliver sustainable social development. Income policies need to be integrated with development policies.

From a partnership perspective, several questions need to be asked. How does government determine the focuses/priorities? How are these communicated to NGOs? How does the government expect that the NGOs will buy into this vision? Is the government enabling or disabling with regard to social development by creating a huge dependency and by so doing fostering counter-development? Does the partnership exist only in 'policy' terms (on paper) or is it visible in implementation and/or practice?

The initiative by local governments to employ community developers is a positive step forward. However, their role as community co-ordinators will require major planning and co-ordination of the NGO sector to get them to join hands with local people and government to reduce poverty and 
facilitate social development. Through communication and negotiations a shared vision can be achieved as to how an enabling environment for social development can be created.

The challenge, therefore, is to find mechanisms to link these short-term poverty-relief programmes with long-term social and economic programmes in order to avoid the creation of another category of the poor. In Gauteng the current Imbizo initiatives ("let us talk"), which link the political head with grassroots communities, can serve as an example. This process enables the MEC to evaluate whether programmes run by the Department are meeting the real grassroots needs of the community. The challenge is to strengthen the Imbizo processes and ensure that there is a feedback loop to the service providers, such as is currently happening in the Gauteng Province. Through this initiative social development programmes can be fast-tracked by the Department of Social Services in those communities where the human development index is very low.

\section{Recognise and balance social development partners' strengths and weaknesses}

It is important that role players in social development understand and overcome the factors that undermine their efforts to build relationships and partnerships for social development.

Too often imbalances in political strength, capabilities and financial power lead to relationships which are neither even-handed nor characterised by reciprocity. This imbalance generates friction, reduces effectiveness, increases transaction costs and discredits the basic principle of development as co-operation (Edwards, 1999 in Fowler, 2000:45).

Such an imbalance is particularly applicable to the relationship and partnership between NGOs and the government. From the perspective of poverty eradication and social development, there is no need for debate on the relevance of such a partnership. According to Fowler (2000:8), since the early 1980 s one of the most visible actors in poverty reduction, outside of governments, has been the non-government development organisations (NGDOs).

Salamon (1995:49) asserts that the relationship between the government and NGOs "can be complex and that it can encounter immense strains and difficulties, especially given somewhat different perspectives of the two sides". For non-profit organisations the strain can be attributed to the tension between their service role and their advocacy role, on the one hand, and between their role as deliverers of government-funded services and their role as critics of government and private policies, on the other (Salamon, 1995:49).

The main source of the strain and complexity in the partnership between government and NGOs is finances. In terms of funding government officials have to balance the partner relationship and the legislative framework such as the PFMA (Public Financial Management Act No. 1 of 1999). Simultaneously, they must help NGOs transform, monitor service delivery as well as exercise management supervision, ensure a degree of accountability, and encourage co-ordination when decision-making authority is widely dispersed and vested in institutions with their own independent sources of authority and support (Salamon, 1995:103). The current funding contract between government and NGOs provides a clear example of the tension between the two partners. This service-level agreement was experienced by some NGOs as threatening and the Department is now reviewing it in order to ensure that the spirit of partnership is ensured, but at the same time maintaining accountability.

It is necessary to find a balance that protects the legitimate public interest in accountability without undermining the characteristics that make non-profit organisations effective partners of government (Salamon, 1995 in Lombard \& Jansen van Rensburg, 2001:331). 
The challenge is thus to understand one another's strengths and negotiate a partnership around them, as opposed to exploiting weaknesses in order to gain power over the relationship. Government is responsible for the social welfare needs of vulnerable groups and should ensure that a long-term vision is developed to meet such needs. Being responsible for the social welfare of its citizens, the government should take the lead in providing the visionary leadership to reduce poverty in South Africa. It appears as if this long-term vision by the government is in the process of being developed through the current initiative to start planning now in order to be in line with the 1995 Copenhagen commitments to have reduced poverty by half in 2015 .

\section{Partners should agree on the social development agenda}

All partners should have an agreement on what the social development agenda entails. This includes consensus, or at least the same terms of reference with regard to what social development entails, in relation to how it can be utilised to address poverty. Currently, there are different interpretations of social development amongst practitioners, academics and government. A major contribution to these differences is a lack of conceptualisation of social development. One example is the equating of social development with community development. Another example is local government that intends to appoint "community developers", when they actually intend to appoint community co-ordinators. Given the lack of a conceptual framework for social development, practitioners and even academics are starting to claim that the 'developmental approach' is not relevant or achievable in South Africa. It is the premise of the authors that it is the lack of knowledge and understanding that inhibits the learning and application of skills to facilitate and achieve social development goals in South Africa. Experience in the classroom with social work Masters students demonstrates how knowledge, understanding and skills development in social development build their capacity and, in turn, how their increased levels of empowerment encourage them to engage in the challenges to facilitate and implement social development. The lack of a clear conceptualisation of social development impacts on the focus and therefore the implementation and impact of social development in addressing poverty in South Africa. The challenge is thus to initiate a joint, collaborated effort between the government, universities, NGOs and donors to train or re-train academics and practitioners to find common ground and develop a vision of how social development can best be achieved in South Africa.

\section{Plan for sustainability of social development}

To ensure the sustainability of social development programmes all role players, including communities, must participate and take ownership of their development, and build their capacity in order to be empowered to sustain the change. Strategies and structures need to be in place to build effective relationships and communication between all parties involved in the partnership.

According to Fowler (2000:22), project outputs should be set against broader criteria of sustained change in indicators of human well-being, capacity growth and empowerment. This author states that the keys to successful participation are commitment and ownership of change.

Sustainability is not only an economic issue; a critical aspect is the termination of a programme due to a lack of funding (Fowler, 2000; Bourke, 1998). Fowler (2000:22) asserts that this problem is compounded by a natural desire of vulnerable people to have NGOs functioning as long as possible. Besides the fact that social development goals are not achieved, the loss of trust by a community in the NGO can have a huge impact on future community participation. If an NGO terminates a programme, the community's perception of the organisation's identity can also change if it becomes incrementally viewed as an extension of bureaucracy or of political interests (Fowler, 2000:22). 
Planning for sustainability is therefore a key aspect in a partnership strategy. All the above challenges should culminate in the final challenge, which is to formulate a partnership strategy for social development. This strategy should be embedded within a negotiated framework between all partners involved and should make provision for different relationships and levels of partnership. Successful partnerships need to be conceptualised within an understanding that "one size does not fit all". This implies that, although a strategy needs to be in place to provide broad guidelines, each kind and level of partnership needs to be uniquely negotiated, planned, designed and maintained.

\section{A partnership strategy for social development}

Government should take the primary responsibility to facilitate the development of a partnership strategy in collaboration with NGOs, the private sector and the community/poor. Poor people have the will, hope and strength to initiate and/or actively participate in interventions to improve their lives (United Nations, 1999). Government has taken up this challenge with the unpacking of the White Paper for Social Welfare (1997) and the Financial Policy (1999), and the ongoing development of norms and standards for service delivery areas.

The United Nations Economic and Social Council Report (1997) states that government should continue to wield major responsibility for the well-being of society and for setting national development goals, while organisations of civil society offer an opportunity for people to participate in and to channel their efforts in an organised manner; and the private sector should be encouraged to recognise its responsibilities for achieving a just society for all in going beyond activities motivated solely by profit (Lombard \& Jansen van Rensburg, 2001:325).

The partnership strategy for social development should include the following components:

- A clear conceptualisation and understanding of the vision for social development;

- Role clarification of all partners involved;

- Outline of the nature of the relationships and levels of partnerships;

- The social development goals to be achieved within the partnership;

- Social development programmes and their relevance to identified goals;

- Capacity building and empowerment approaches to be utilised;

- Key indicators for sustainability of social development programmes;

- Project management process;

- Resources, including funding, and people;

- Accountability for outcomes through monitoring and evaluation/research processes;

- Criteria for withdrawal from social development programmes;

- Clear indication of the leadership qualities required to facilitate the implementation of the strategy;

- A clear communication strategy between the government and NGOs and other partners in social development;

- A costing model for partnerships linked to government's responsibility for the transformation of services. 


\section{CONCLUSION}

In order to reduce poverty partnerships should be built on a strong commitment to an agreed upon social development agenda for South Africa. The greatest challenge facing partners in social development is to keep their focus on the poor. Partners should adopt a holistic, integrated view of how social development can reduce poverty and their work should be shaped and driven by this vision - not by their power base and/or personal agenda.

Government should avoid falling "into the trap of undertaking too much with too few resources" (World Bank, 1997 in George, 2003:20) and rather create an enabling environment and actively engage the NGO sector in public sector contracts. Dr Zola Skweyiya, Minister of Social Development acknowledged this in his Budget Vote Speech (15 May, 2003) as follows: "However, due to a decreased personnel budget, we cannot deliver on our mandate unless we have the right numbers and skills at the delivery point". The NGO sector should be allowed to fill this gap. In so doing NGOs should retain their watchdog, advocacy and campaigning functions which have historically been central to genuine community participation (Mayo \& Craig, 1995:7). This approach is in line with a context of political democracy, which allows freedom of choice and political action (George, 2003:20).

All partnerships for social development should be embedded within a negotiated framework of freedom of choice, which allows for the building of relationships that are fair and just, and acknowledge partners' strengths. The premises for strong partnerships for social development lie within the fact that the war on poverty is too big to be fought in an individual, uncoordinated manner. Government and NGOs can invest in a strong partnership among and between themselves in order to reach the poor and the vulnerable in a sustainable, accountable manner, including measuring the impact of poverty reduction on the poor.

If the government is, as it says it is, serious about social development, it will create an enabling environment for partnerships that will facilitate mutual trust amongst all role players involved. The key to meeting the challenges for building successful partnerships for social development lies in visionary leadership, both within the government itself and between government, the NGO sector and the community. Matube (2000:3) notes that organisations and programmes survive on excellent management and leadership skills. The final challenge is to find and apply these skills through a partnership that can reduce poverty according to a well-planned and sustainable social development strategy.

\section{BIBLIOGRAPHY}

ANC. 1994. The Reconstruction and Development Programme: A Policy Framework. Johannesburg: Umanyano Publications.

BOURKE, P. 1998. From community development to community economic development in South Wales: a case study. In: TWELVETREES, A. (ed) 1998. Community economic, rhetoric of reality? London: Community Development Foundation.

CRANKO, P. \& KHAN, F. 1999. Municipal community partnerships. Isandla Institute.

DRAFT CONSOLIDATED REPORT. 2002. Report of the Committee of Inquiry into a Comprehensive System of Social Security for South Africa. Transforming the present protecting the future. Chaired by Prof. V Taylor. March 2002.

ESTES, R.J. 1999. The poverties: Competing definitions and alternative approaches to measurement. Social Development Issues, 21(2):11-21. 
FOULIS, C. 2001. Many guests at the table. Different ways of seeing and working in partnerships. ODDebate, March 2002:11-15.

FOWLER, A. 2000. Civil society, NGDOs and social development: Changing the rules of the game. United Nations Research Institute for Social Development. Occasional Paper. Geneva 2000.

FOWLER, A. 2001. Beyond partnerships: Getting real about NGO relationships in the aid system. Introduction to IDS Bulletin, 31(3):16-19. Edited extract of a paper first printed as an INTRAC occasional paper: Fowler, A. 2000. Partnerships: Negotiating Relationships - a resource for nongovernment development organisations. Occasional Paper Series, 32. Oxford: INTRAC.

GEORGE, U. 2003. Strategies for social development: Lessons from Kerala's experience. Social Development Issues, 24(1):15-24.

LOMBARD, A. \& JANSEN VAN RENSBURG, A. 2001. Coalitions: A practice framework for sustainable development. Social Work/Maatskaplike Werk, 37(4):325-342.

LOMBARD, A. 2002. Entrepreneurship in Africa: Challenges for human, social and economic development. Entrepreneurship in Africa: The road to freedom. International Conference Proceedings, 3-4 October 2002. Presented by Technikon Pretoria in co-operation with Polytechnic of Namibia.

MATUBE, J. 2000. Sustainable development. Guest lecture for fourth year students at the University of Pretoria. Pretoria, 10 February 2000.

MAYO, M. \& CRAIG, G. 1995. Community participation and empowerment: The human face of structural adjustment or tools for democratic transformation. In: GRAIG, G. \& MAYO, M. (ed) Community empowerment. A reader in participation and development. London: Zed Books.

MAY, J. (ed) 1998. Poverty and inequality in South Africa. Summary Report prepared for the Office of the Executive Deputy President and the Inter-Ministerial Committee for Poverty and Inequality. 13 May.

MINISTER OF SOCIAL DEVELOPMENT, Dr Zola Skweyiya. 2003. Budget Vote Speech to the National Council of Provinces. Cape Town, 15 May 2003.

REPORT OF THE COMMITTEE OF INQUIRY INTO A COMPREHENSIVE SYSTEM OF SOCIAL SECURITY IN SOUTH AFRICA. 2002. Transforming the Present - Protecting the Future. Draft Consolidated Report. March 2002.

RSA MINISTRY FOR WELFARE AND POPULATION DEVELOPMENT. White Paper for Social Welfare. Notice 1108 of 1997. Vol. 386. No. 18166. Government Gazette. Pretoria. 8 August.

R.S.A. DEPARTMENT OF WELFARE. Financing Policy. Developmental Social Welfare Services. Government Gazette, 405 (19888). Pretoria, 26 March 1999.

R.S.A. MINISTRY OF FINANCES. Public Finance Management Act, No 1 of 1999. Available: http://www.acts.co.za/public_fin_man/

R.S.A. GAUTENG DEPARTMENT OF SOCIAL SERVICES AND POPULATION DEVELOPMENT. 2003. Poverty Sub Directorate. Discussion document on a Poverty Reduction Strategy. Strategic Planning Session of Top Management. Document compiled by Mulalo Nemavhandu, Programme Manager.

SALAMON, L.M. 1995. Partners in public services. Government-non-profit relations in the modern welfare state. Baltimore and London: The Johns Hopkins University Press.

SWANEPOEL, H. \& DE BEER, F. 1996. Community capacity building. A guide for fieldworkers and community leaders. South Africa: International Thomson Publishing (Pty) Ltd. 
UNITED NATIONS. 1999. Participatory Approaches to Poverty Alleviation in Rural Community Development. Department of Economic and Social Affairs Division for Social Policy and Development. USA.

WORLD BANK. 1997. World Development Report: The State in a Changing World. Washington: Oxford University Press. 